\title{
Role of Grandparents in Childhood Obesity during First Two Years of Life
}

\author{
Jeanne H Freeland-Graves1*, Deborah B Jacobvitz2 and Prageet Sachdev3 \\ ${ }^{1}$ Bess Heflin Centennial Professor in Nutritional Sciences, T.S Painter Hall 5.20, The University of Texas at Austin, Department of \\ Nutritional Sciences, College of Natural Sciences, 103 W 24TH ST A2703, Austin, Texas 78712, United States \\ ${ }^{2}$ Professor in Child Development, The University of Texas at Austin, School of Human Ecology, College of Natural Sciences \\ 200 W. 24th St. A2700, Austin, TX 78712, United States
}

3T.S Painter Hall 3.18, The University of Texas at Austin, Department of Nutritional Sciences, College of Natural Sciences

103 W 24TH ST A2703, Austin, Texas 78712, United States

Received: August 01, 2018; Accepted: August 21, 2018; Published: August 31, 2018

*Corresponding author: Jeanne Freeland-Graves, Bess Heflin Centennial Professor in Nutritional Sciences, T.S Painter Hall 5.20, The University of Texas at Austin, Department of Nutritional Sciences, College of Natural Sciences, 103 W 24TH ST A2703, Austin, Texas 78712, United States, E-mail: jfg@mail.utexas.edu

\begin{abstract}
Introduction: Childhood obesity is a public health problem in the United States. One consideration that remains relatively unexplored is the influence of the grandparent on weight status of the grandchild in ages 0-2 years. The aim of this paper is to synthesize the literature on a) influence of grandparents' involvement on child weight gain; b) influence of grandparents' involvement on breastfeeding behaviors and associated obesity risk; c) effects of grandparents' support about nutrition, cooperative co-parenting, knowledge, attitudes, beliefs and body mass index on feeding practices and weight gain; d) impact of child temperament and weight status on grandparent feeding practices; e) contribution of cultural norms and acculturation on child weight gain in ages $0-2$ years.

Method: A literature search of Embase, PubMed, Cochrane Library and Web of Science databases was conducted. A total of 64 studies published between January 1980 and January 2017 met the inclusion criteria.

Results: At present, only few studies have investigated whether grandparent involvement is related to feeding practices and subsequent weight outcomes in children aged 0-2 years, with the actual inclusion of the grandparents. Most of these studies suggest a negative association between grandparent characteristics and child weight gain. Challenges exist in studying this topic, which include, defining a "good diet" for young children, measurement of infant diet, confounding, reporting bias, reverse causality and the difficulties of randomized intervention designs in infant feeding.

Conclusion: Identification of grandparent characteristics associated with lower obesity risk may provide health professionals the tools to create effective interventions for obesity prevention.
\end{abstract}

Keywords: Grandparents; childhood obesity; nutrition; acculturation; Running title: Grandparents and childhood obesity;

\section{Introduction}

Childhood obesity is a public health problem in the United States (U.S.). According to the National Health and Nutrition Examination Survey (NHANES) data of 2015-2016, the prevalence of obesity in children ages $2-5$ years is $13.9 \%$ [1]. For infant and toddlers from birth to age 2 years, the high-weight for recumbent length was $8.1 \%$ in 2012 [2]. A racial disparity exists, with a prevalence of high-weight for recumbent length of $6.6 \%$ for Whites, 9.4\% for Hispanics and $8.4 \%$ for Blacks [2]. The risk of obesity in low-income households is even greater; with $14.5 \%$ of those aged 2 to 4 years in Women, Infants and Children programs classified as obese [3]. The obesogenic environment in the U.S. and other countries has been related to the high availability, variety and portion size of food [4]; an exponential increase in screen time [5]; and a greater number of working women, who rely more on caregivers outside the home to feed the infant $[6,7]$.
One consideration for increased obesity that remains relatively unexplored is the influence of the grandparent on the weight status of the grandchild in early infancy.

Grandparents may have a significant impact, as epidemiological evidence suggests that obesity is transmitted across multiple generations [8]. It is well established that obese children tend to have grandparents and parents who also are obese. In the British Millennium Cohort of children, ages 9 months to 3 years, those who were cared for mainly by their grandparents were more likely to be overweight at the age of 3 years, compared to those who had parents that were primarily the caregivers [9]. Whether this is due to genetics or environment is unknown. Yet environment must undoubtedly play a critical role, as the genes of humans have not changed significantly in the past few decades.

The percentage of children living in grandparent-maintained households has doubled from $3 \%$ in 1970 to $6 \%$ in 2012 [10]. 
In the households of 7 million grandparents who live with grandchildren, about 2.7 million are the primary caregivers for their co-resident grandchildren ( $<18$ years) (Figure 2). In addition, one-third of infants are cared for by grandparents [11]. With children of Hispanic descent, involvement of grandparents has always been greater than other ethnicities, with $43 \%$ acting as care providers [12]. Geographical variation of grandparent-led households also exists, with more grandchildren living in their grandparents' home in the West coast and Southwestern U.S than other locations [10].

\section{Methods and Materials}

\section{Data Sources and Search Strategy}

A comprehensive literature search was conducted to identify relevant prospective, case-controlled cross-sectional and review papers investigating the a) influence of grandparents' involvement on weight gain; b) influence of grandparents' involvement on breastfeeding behaviors in mothers and the associated obesity risk; c) effects of grandparents' support about nutrition, cooperative co-parenting, nutrition knowledge, attitudes, beliefs and body mass index on feeding practices and subsequent weight gain trajectories; d) impact of child temperament and weight status on grandparent feeding practices; and e) contribution of cultural norms and acculturation on child weight gain in ages 0-2 years. The electronic databases of PubMed, Embase, Web of Science and Cochrane Library were searched. The reference list of selected articles and reviews on the topic also were searched. A total of studies were 5310 research papers were extracted, using the search terminologies of (grand* and child*), (grand* and feeding*), (grand* and weight*), (grand* and temperament*), (grand* and nutrition*), (grand* and culture*). The studies finally retrieved were then subject to the exclusion criteria (Figure 1).

\section{Inclusion and Exclusion Criteria}

All potentially relevant publications were reviewed independently by two graduate students using the inclusion criteria. The results were later matched and any discrepancy was addressed by the third reviewer, who was the lead professor on this paper. Inclusion criteria were: 1) prospective, cross-sectional, case-control investigations or review papers; 2) population of interest was grandparent, parent and child; 3) outcome of interest was breastfeeding/feeding practices and weight gain in child; 4) studies on influence of child temperament and weight status on grandparent feeding practices; 5) publication date between January 1980 and January 2017,6) written in the English language, 7) U.S and non-U.S. studies. Studies where grandparent was the primary caretaker and those articles that covered health outcomes other than that of feeding practices and weight were excluded.

\section{Results}

Figure 1 illustrates the selection process, resulting in a total of 64 studies. Four tables have been included that highlight characteristics of 36 of these 64 studies.

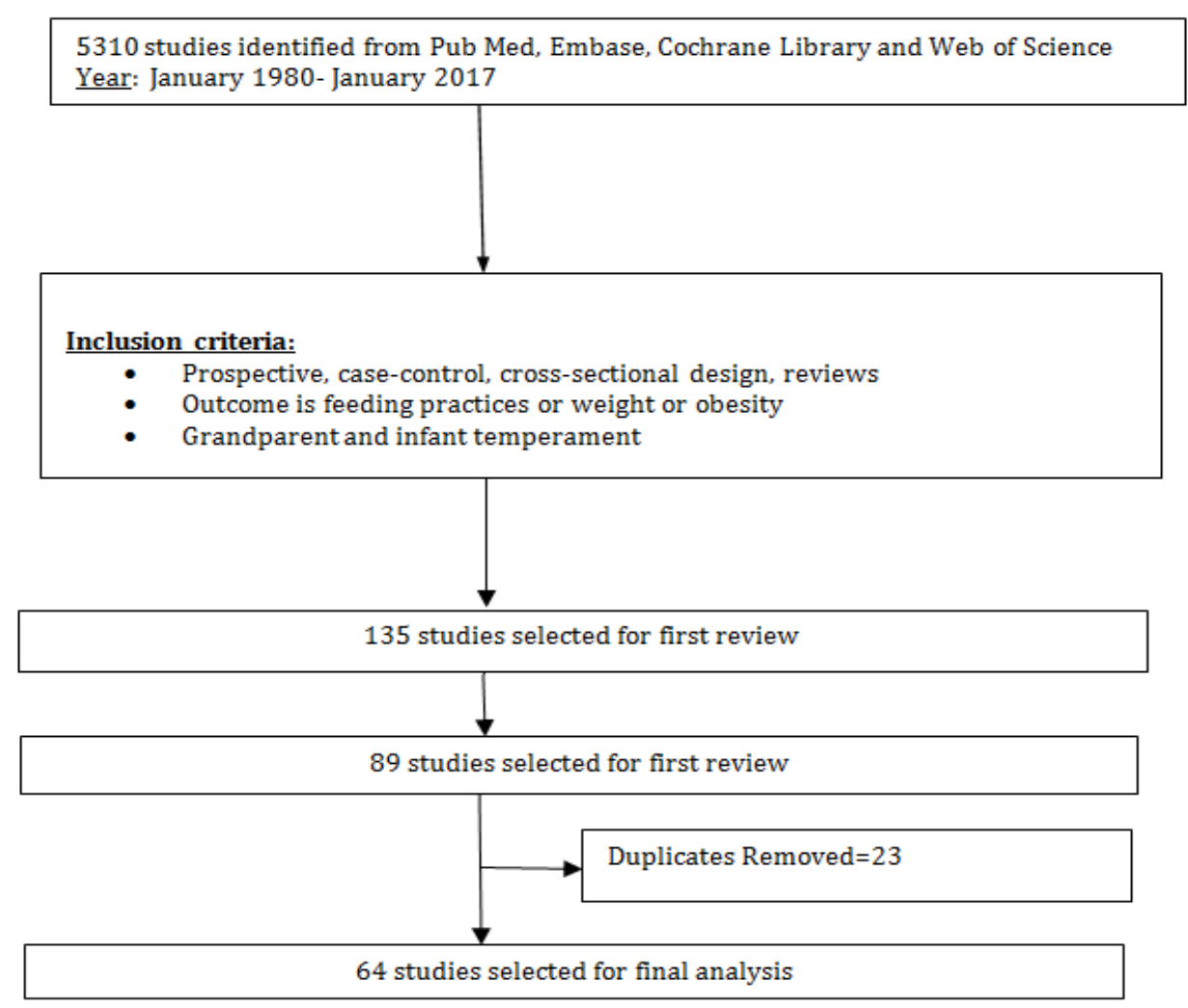

Figure 1: Flowchart illustrating the process of study selection 


\section{Influence of grandparents on child weight and obesity risk}

In the past and in traditional societies, grandmothers positively impacted nutritional status of grandchildren and augmented survival rates. Yet as societies have evolved, grandmother engagement has been associated with increased risk of child overweight $[7-9,13]$. Why and how does the presence of a grandparent have potential adverse health effects for enhanced child weight and obesity risk? The paradox certainly merits attention in obesity prevention efforts. Table 1 illustrates detailed findings of studies that have investigated associations between children living with, or cared for, by grandparents and risk of overweight/ obesity $[9,12,14,15,16,17,18,19,20]$. In a recent systematic review by Pulgaron et al., five studies have shown an adverse association between grandparents' involvement and weight gain in children [20]. In three-generation households in Japan, the risk of being overweight or obese was higher in 3-6year olds with a grandparent [15]. In contrast, Cunningham et al found no significant associations in South Africa [19]; while Jiang et al. reported a negative association between residence with grandparent and infant's weight in China [14]. Note that minimal research has been conducted on grandparents' influence on child weight in children less than the age of 3 years.

\begin{tabular}{|c|c|c|c|}
\hline Reference, Country & Study Design & Child Age & Major Findings \\
\hline Pearce et al. (9) & Millennium Cohort & \multirow[t]{2}{*}{9 mo. -3 years } & \multirow{2}{*}{$\begin{array}{c}\text { Children cared for mainly by grandparents were more } \\
\text { likely to be overweight at age } 3 \text { than with parent } \\
\text { caregivers }\end{array}$} \\
\hline U.K. ${ }^{b}$ & $\mathrm{n}=18,296$ & & \\
\hline Pulgaron et al. (12) & Cross sectional & \multirow[t]{2}{*}{$5-10$ years } & \multirow{2}{*}{$\begin{array}{l}\text { Grandparent involved in caretaking was associated with } \\
\text { lower z BMI for Hispanic children, but not Cubans }\end{array}$} \\
\hline U.S. ${ }^{c}$ & $\mathrm{n}=199$ & & \\
\hline Jiang et al. (14) & Cross sectional & \multirow[t]{2}{*}{$0-5$ years } & \multirow{2}{*}{$\begin{array}{l}\text { Prevalence of overweight and obesity was lower }(12.8 \%) \\
\text { in children in three-generational household than in } \\
\text { children in nuclear families }(18.8 \% \text { ) (p value < } 0.0807 \text { ) }\end{array}$} \\
\hline China & $\mathrm{n}=686$ & & \\
\hline Wantanabe (15) & Cross-sectional & \multirow[t]{2}{*}{ 3-6 years } & \multirow{2}{*}{$\begin{array}{l}\text { Three-generation co-residence was significantly } \\
\text { associated with child overweight and obesity after } \\
\text { controlling for mother's employment (OR=1.59) }\end{array}$} \\
\hline Japan & $\mathrm{n}=1765$ & & \\
\hline Li et al. (16) & Cross-sectional & \multirow[t]{2}{*}{$8-10$ years } & \multirow{2}{*}{$\begin{array}{l}\text { Children co-residing with grandparents were more likely } \\
\text { to be overweight/obese }\left(\mathrm{OR}^{\mathrm{a}}=1.72\right)\end{array}$} \\
\hline China & $\mathrm{n}=497$ & & \\
\hline Formisano et al. (17) & Cross-sectional & \multirow[t]{2}{*}{ 7-9 years } & \multirow{2}{*}{$\begin{array}{l}\text { Children who lived with grandparents had higher } \mathrm{z} \text { body } \\
\text { mass index (zBMI) scores than with parents or one parent } \\
\text { and partner }\end{array}$} \\
\hline Italy & $\mathrm{n}=12,350$ & & \\
\hline Tanskanen et al. (18) & U.K. Millennium Cohort & \multirow[t]{2}{*}{9 mo.-3 years } & \multirow{2}{*}{$\begin{array}{c}\text { Children who were cared for mainly by grandparents } \\
\text { were more likely to be overweight at age } 3 \text { than with } \\
\text { parent caregivers; risk of being overweight was equal } \\
\text { with maternal and paternal grandmothers }\end{array}$} \\
\hline U.K. & $\mathrm{n}=14,630$ & & \\
\hline Cunningham et al. (19) & Longitudinal & Newborn & \multirow{2}{*}{$\begin{array}{l}\text { Women had heavier newborns if their mother was alive; } \\
\text { no additional association between co-residence with } \\
\text { grandparents and birth weight }\end{array}$} \\
\hline South Africa & $\mathrm{n}=3,993$ & & \\
\hline
\end{tabular}

\section{Influence of grandparents on breastfeeding and introduction of complementary food}

Possible reasons for an increase in the risk of overweight/ obesity in children could be that grandmothers influence both breastfeeding behaviors and initiation of complementary foods (Table2). Some studies have suggested that lack of support from grandparents for breastfeeding has a negative influence on the probability of initiation [21] and duration of breastfeeding in women $[22,23,24]$. In contrast, Mahoney et al. reported that grandmother's encouragement for breastfeeding increased the likelihood of breastfeeding by 12 -fold.
The effects of the early introduction of complementary food by grandmothers have been investigated by a number of researchers [27, 28, 29, 30, 31]. In Australia, mothers reported that older women in their house pressured them to introduce complementary food before the age of 6 months [31]. But none of these studies have investigated the effect of these practices on child weight.

Early introduction of complementary food has been linked to rising weight gain trajectories [32] for those weaned prior to 2 [32], 3 [33], 4 [34, 35], or 5 months [36]. Meta-analysis studies have found an inverse association between duration 


\begin{tabular}{|c|c|c|}
\hline $\begin{array}{l}\text { Reference, } \\
\text { Country }\end{array}$ & Study Design & Major Findings \\
\hline Emmott et al. (21) & Longitudinal cohort & \multirow{2}{*}{$\begin{array}{l}\text { Mothers with less frequent contact with maternal grandmothers were more likely to } \\
\text { initiate breastfeeding }(162.4 \%) \text { and less likely to terminate breastfeeding }(25.1 \%)\end{array}$} \\
\hline U.K. & $\mathrm{n}=18,827$ & \\
\hline Kaneko et al. (22) & Cross-sectional & \multirow{2}{*}{$\begin{array}{l}\text { Positive association between not living with grandparents of infants with } \\
\text { breastfeeding status at } 6 \text { months }\left(\mathrm{OR}^{\mathrm{a}}=1.14\right)\end{array}$} \\
\hline Japan & $\mathrm{n}=53,575$ & \\
\hline Liu et al. (23) & Prospective cohort study & \multirow{2}{*}{$\begin{array}{l}\text { Shorter duration of breastfeeding associated with grandparents residing within } \\
\text { same province }\end{array}$} \\
\hline China & $\mathrm{n}=681$ & \\
\hline Susin et al. (24) & Prospective & \multirow{2}{*}{$\begin{array}{l}\text { Grandparents' advice to use another milk to feed the child increased risk for early } \\
\text { termination of breastfeeding by } 2.4 \text { times }\end{array}$} \\
\hline Brazil & $\mathrm{n}=1202$ & \\
\hline Mahoney et al. (25) & Cross-sectional & \multirow{2}{*}{$\begin{array}{l}\text { Direct association between encouragement from woman's mother to breastfeed and } \\
\text { anticipated breastfeeding }\left(\mathrm{OR}^{\mathrm{c}}=12.4\right)\end{array}$} \\
\hline U.S & $\mathrm{n}=66$ & \\
\hline Baughcum (27) & Focus groups & \multirow{2}{*}{$\begin{array}{l}\text { Introduced rice cereal and other solid food to diets before recommended ages. } \\
\text { Grandmothers were main source of information regarding infant feeding }\end{array}$} \\
\hline U.S & $n=29$ & \\
\hline Ingram et al. (28) & Educational intervention & \multirow{2}{*}{$\begin{array}{l}\text { Early introduction of solid food at } 3 \text { months; rice dishes, cereals, daal and watery } \\
\text { soups recommended by grandmothers. An antenatal educational intervention on } \\
\text { breastfeeding for grandmothers increased their support for exclusive breastfeeding }\end{array}$} \\
\hline South East Asia & $\mathrm{n}=93$ & \\
\hline Bentley et al. (29) & $\begin{array}{l}\text { Women, Infant, Children } \\
\text { intervention }\end{array}$ & \multirow[t]{2}{*}{$\begin{array}{l}\text { Mothers who received information from WIC providers were more likely to delay } \\
\text { introduction of complementary foods vs. reliance primarily on grandmother's advice }\end{array}$} \\
\hline U.S. & $\mathrm{n}=171$ & \\
\hline Kerr et al. (30) & Semi-structured interviews & \multirow[t]{2}{*}{$\begin{array}{l}\text { Grandmothers introduced solid food within first month; } 65 \% \text { children given food in } \\
\text { the first month }\end{array}$} \\
\hline Malawai & $\mathrm{n}=183$ & \\
\hline Walsh et al. (31) & $\begin{array}{l}\text { Semi-structured interviews with } \\
\text { mothers }\end{array}$ & \multirow[t]{2}{*}{ Grandmothers increased likelihood of early introduction of complementary food } \\
\hline Australia & $\mathrm{n}=21$ & \\
\hline
\end{tabular}

of breastfeeding and risk of childhood obesity [37, 38, 39]. Yet, a systematic review by Vail et al. documented a neutral effect on infant growth in high-income countries for those weaned between 3 and 6 months [40]. To date, there remains a lack of evidence on feeding practices and weight in U.S. children younger than age 2, except for breastfeeding studies. Grandparents are likely to influence when parents introduce solid foods, as well as parents' feeding styles and choices of what to feed. Therefore, the first two years may be a particularly important time to investigate the effects of grandparents on parental feeding practices.

\section{Effects of Co-Parenting}

The effect of the quality of mother-father co-parenting on health outcomes in children has been the subject of several reports $[41,42]$. In competitive co-parenting, each parent attempts to have control of the child and places the child in the middle of conflicts. The influence of grandparents on co-parenting with the mother is less clear. When a grandparent disagreed with a parent about feeding, higher BMI z scores were documented in 5-12 yr. old of Hispanic descent [11]. In contrast, responsiveness and support of parents by a grandparent may promote healthy eating behaviors and reduce overly controlling or indulgent feeding practices associated with child overweight [43]. Observational ratings of support and responsive communication in grandmother/mother interactions have been associated with increased sensitivity and responsiveness of mothers to infant cues during feeding at 6 and 9 months [44, 45]. Additionally, expectant mothers who describe their own parents as responsive and sensitive [vs. unloving, rejecting] exhibited comparable qualities with their children at $8[46,47] 12$ to 15 [48], 24 months $[46,49,50]$. These mothers were more likely to recognize and respond appropriately to cues of satiety by the baby and less likely to restrict food intake [51].

One result of cooperative co-parenting is that it may facilitate the maintenance of a structured environment at home. In a longitudinal analysis in the United Kingdom, Anderson et al. 
documented that emotional self-regulation in children at the age of 3 years was a predictor of risk of obesity at age 11 [52]. Cooperative grandparent-parent interactions and grandparent's support for reducing the inconsistencies in the daily mealtime patterns could lead to better emotional regulation in the child and help prevent weight gain [52]. While some grandparents assume great responsibility for the child's health, others coparent jointly or assist only part-time [53]. Those with a higher degree of involvement presumably have a greater impact on the quantity and nutritional quality of the child diet.

Effect of successful grandparent characteristics on eating and subsequent reduction in grandchild obesity risk

A new baby represents a window of opportunity for transmission of knowledge and eating practices across generations. At this time in life, adolescents and young adults often turn to their parents to seek assistance on how, and how much, to feed the new baby. Thus, several grandparent characteristics [high diet quality, knowledge, attitudes and beliefs about nutrition; and Body Mass Index [BMI]] may influence feeding practices and subsequent weight gain trajectories in the grandchild.

The degree of nutrition knowledge of the grandparent may be critical in influencing obesity risk. Although knowledge of nutrition does not always translate into desirable eating behaviors, sound information is needed to plan a nutritionally adequate diet. Greater fruit and vegetable intakes of children have been linked to better nutrition knowledge of the mother [54]. Table 3 shows the characteristics of studies that assessed nutrition knowledge and eating behaviors of grandparents [5566]. Ganthavorn et al. (2007) observed increased consumption of fruits and vegetables by grandparents after participation in a nutrition and physical activity intervention [61]. In a nutrition education program in Sierra Leone, it was observed that the percentage of grandmothers who advocated the initiation of breastfeeding within an hour of birth, increased from $78 \%$ to $100 \%$ at the end of the 3 years of the program [62].

\begin{tabular}{|c|c|c|}
\hline Reference, Country & Study Design & Major Findings \\
\hline Jiang et al. (14) & Cross sectional & \multirow[t]{2}{*}{ Grandparents had less nutrition knowledge than parents ( 8.9 vs $8.4, \mathrm{p}<0.01$ ) } \\
\hline China & $\mathrm{n}=686$ & \\
\hline \multirow[t]{2}{*}{ Higgins et al (55) } & Semi-structured & \multirow{3}{*}{$\begin{array}{l}\text { Primary caregiver grandparents reported providing more nutritious goods to } \\
\text { their grandchildren than what they had given to own children }\end{array}$} \\
\hline & Interviews & \\
\hline U.S. & $\mathrm{n}=48$ & \\
\hline \multirow[t]{2}{*}{ Aubel et al. (58) } & Nutrition education & \multirow{3}{*}{$\begin{array}{c}\text { Grandmothers (93\%) advised exclusive breastfeeding after learning about } \\
\text { healthy infant feeding practices }\end{array}$} \\
\hline & intervention, 12 months & \\
\hline Sengel & $\mathrm{n}=150$ & \\
\hline Tan et al. (59) & Interviews & \multirow{2}{*}{$\begin{array}{l}\text { Non-parent caregivers (grandparents/relative) had lower nutrition } \\
\text { knowledge than parents ( } 52.2 \text { vs } 63.8 \% \text { ) }\end{array}$} \\
\hline China & $\mathrm{n}=3361$ & \\
\hline \multirow[t]{2}{*}{ Kicklighter et al. (60) } & Nutrition \& physical & \multirow[t]{3}{*}{ Nutrition knowledge of grandparents increased post intervention } \\
\hline & activity intervention, 5 months & \\
\hline U.S. & $\mathrm{n}=22$ & \\
\hline \multirow[t]{2}{*}{ Ganthavorn et al. (61) } & Nutrition \& physical & \multirow{3}{*}{$\begin{array}{l}\text { Caregiver grandparents had improved healthy eating behaviors (eating more } \\
\text { fruits, green salad, and vegetables). Grandchildren had similar improvements } \\
\text { in food choices }\end{array}$} \\
\hline & activity intervention, 8 weeks. & \\
\hline U.S. & $\mathrm{n}=24$ & \\
\hline \multirow{2}{*}{$\begin{array}{l}\text { Ministry of Health, } \\
\text { World Vision Germany } \\
\text { Sierra Leone (62) }\end{array}$} & Nutrition education intervention, 3 years & \multirow{2}{*}{$\begin{array}{c}\text { Grandmothers' nutrition knowledge increased. Those who received nutrition } \\
\text { intervention had higher proportion }(90.2 \%) \text { of exclusively breastfed infants } \\
(0-23 \text { months }) \text { than those who did not }(79.4 \%)\end{array}$} \\
\hline & $\mathrm{n}=884$ & \\
\hline \multirow[t]{2}{*}{ Duquin et al. (63) } & Health \& wellness & \multirow{3}{*}{$\begin{array}{l}\text { Grandparents reported greater awareness and used more nutrition in care- } \\
\text { giving of grandchildren }\end{array}$} \\
\hline & intervention, 12 weeks. & \\
\hline U.S. & $\mathrm{n}=41$ & \\
\hline \multirow[t]{2}{*}{ Eli et al. (64) } & Semi structured & \multirow{3}{*}{$\begin{array}{c}\text { Grandmothers and mothers had similar knowledge of adverse health effects } \\
\text { of sugary beverages; some conflicts in knowledge regarding health effects of } \\
\text { providing juice to children }\end{array}$} \\
\hline & interviews & \\
\hline U.S. & $\mathrm{n}=49$ & \\
\hline \multirow[t]{2}{*}{ Jingxiong et al. (65) } & Semi-structured & \multirow{3}{*}{$\begin{array}{l}\text { Most grandparents wanted nourishing food for their families and believed } \\
\text { that meat was a nutritious component of the diet. Others used high salt and } \\
\text { sugar in preparing family meals }\end{array}$} \\
\hline & interviews & \\
\hline China & $\mathrm{n}=23$ & \\
\hline${ }^{a}$ United States & & \\
\hline
\end{tabular}


Yet the translation of knowledge into action is modulated considerably by one's beliefs. A review of qualitative studies of parents of preschoolers identified beliefs about eating that promoted obesogenic behaviors [66]. These included uses of food to shape a child's behavior and perceptions that underweight is a cause for concern $[67,68,69]$. In an intervention tailored for mothers of young children, Freeland-Graves concluded that overweight/obese mothers who modified their eating related cognitions (attitudes/beliefs) made comparable changes in the diet quality of their 1-3year-old children [70]. Similarly, an educational intervention in 542 mothers of 4-month olds improved diet quality [71]. No reports have been found that document how grandparents affect grandchild diet quality in post-weaning.

Only a few studies have investigated the effect of parent/ grandparents' BMI on the BMI of the child [72,73]. In 84 threegenerational families of Native Americans and African Americans, a significant correlation was observed between BMIz scores of the child and BMI of grandparents [10]. In U.S. elementary school children, grandparent involvement was associated with lower BMI z-scores in Hispanics, but not with Cubans [11]. Thus, a lack of research exists regarding the influence of grandparents' characteristics on feeding practices and weight gain in post weaning children.

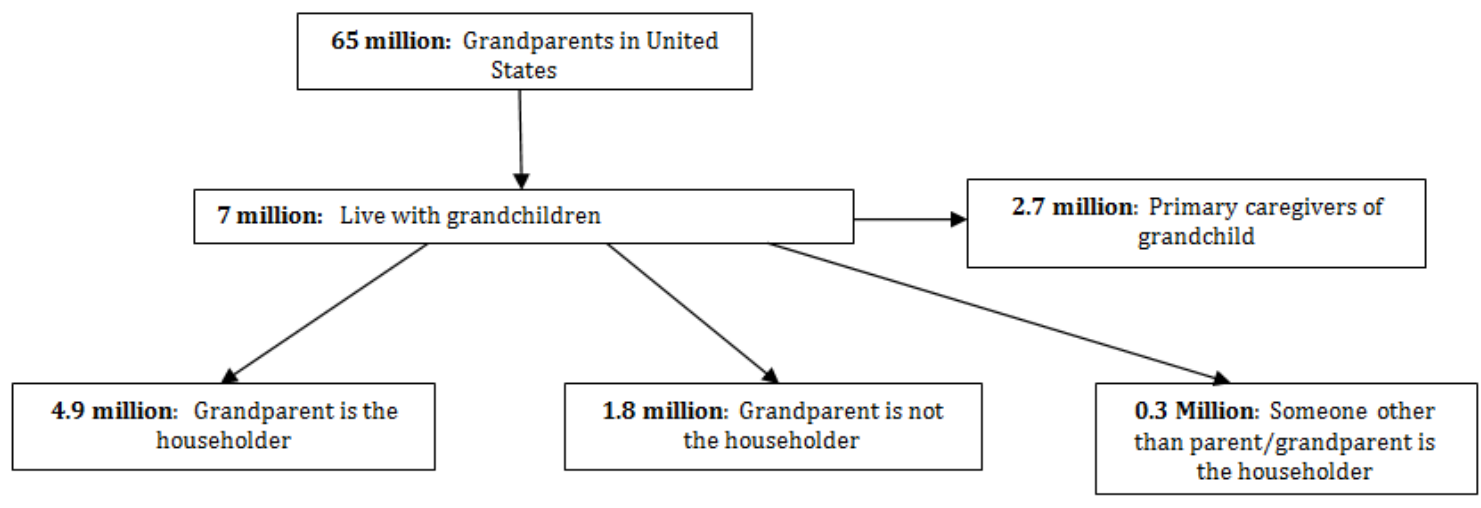

Figure 2: Grandparents living with/or cared by grandparents: United States (U.S.) Census 2012 (10)

Effects of child temperament and weight on grandparent and parent feeding practices

It is well established that child temperament and weight status affect parent feeding practices, resulting in weight gain in children [74,75]. When children are calm and easy, it is enjoyable to feed them. But fussy and irritable infants are more demanding for both grandparent and parent who may disagree about the best responses to the child. Such disagreements can reduce receptiveness of the parent to advice, resulting in less grandparent responsiveness and support of parents' feeding practices. Although previous studies have established the existence of a bidirectional relationship between parent and child the tri-directional effects of child temperament and weight status on parent and grandparent feeding practices are yet to be studied $[74,75]$.

It is believed that the fussy child may be more prone to gaining weight. Slining et al. reported that infant distress to limitations was associated with increased weight at 3, 6, 9, 12 and 18 months of age and greater weight-for-length at 12 months [75]. In a crosssectional investigation of 217 mothers, mothers were more likely to initiate complementary food before 4 months if they perceived their infants to be fussy [76]. In a systematic review, Bergmeier et al. Documented that the temperament characteristics of being difficult to feed, distress to limitations and low soothability were all significantly associated with weight gain rates in infants [77]. These relationships appear to be mediated by maternal feeding practices of using food to calm a fussy or difficult child.

\section{Infant Weight and Feeding Practices}

The effect of infant's weight on feeding practices of parents has been investigated [78, 79]. A high concern by mothers about the weight of the infant, assessed retrospectively at 3 years, influenced the amount and type of food fed and predicted higher fat mass in children at age 5 [78]. It is well known that perceptions of grandparent and parent that "bigger is healthier" may contribute to obesogenic feeding practices of young children [80]. Thus, weight status may influence grandparent and parent beliefs about child feeding practices, with subsequent effects on child diet and weight.

\section{Influence of cultural norms, race/ethnicity and degree of acculturation on child weight}

Human behavior is shaped extensively by the social and cultural environment. Transmission of cultural norms over generations is known to affect feeding practices and child weight. Table 4 highlights studies that reported the influence of cultural norms and race/ethnicity in feeding practices and subsequent 
obesity risk in children [81, 82, 83, 84, 85, 86, 87]. In Hispanics, mothers perceived a "chubbier" body type as ideal for infants and toddlers [88]. Latino mothers have reported that child weight was reflective of parenting skills, such that a skinny child suggested a bad parent and only fat kids were perceived to be healthy [81]. In African-American mothers, it was reported that it was culturally acceptable to have a large body size, as long as the child was healthy and held high self-esteem [83]. Furthermore, the degree of acculturation may significantly change breastfeeding behaviors in women $[89,90]$. Kimbro et al. observed that Mexican immigrants were more likely to breastfeed for longer time periods than Mexican-Americans who exhibited similar behaviors as U.S. white mothers [84]. In mothers enrolled in the Women, Infant and Children's Program, less acculturated mothers were more concerned about the weight of their children and pressured them to eat more [91]. Also, Spanish-speaking Hispanic participants had a greater tendency to use food to calm their children, as compared to those who spoke English [86]. Additional research is needed to understand the influence of grandparents' involvement on childhood obesity within the context of culture, race/ethnicity and degree of acculturation.

Table 4: Studies that illustrate influence of cultural norms, race/ethnicity and acculturation on feeding practices.

\begin{tabular}{|c|c|c|c|}
\hline $\begin{array}{c}\text { Reference, } \\
\text { Country }\end{array}$ & Study Design & Ethnicity & Major Findings \\
\hline Jingxiong et al. (65) & Semi-structured & \multirow[t]{3}{*}{ Chinese } & \multirow{3}{*}{$\begin{array}{l}\text { Grandparents believed that children who } \\
\text { were heavier at young age would have better } \\
\text { nutritional status when grown and urged child to } \\
\text { eat heavier portions }\end{array}$} \\
\hline & interviews & & \\
\hline China & $\mathrm{n}=23$ & & \\
\hline Lindsay et al. (81) & Focus groups & \multirow[t]{2}{*}{ Latino } & \multirow{2}{*}{$\begin{array}{l}\text { Mothers reported that grandmothers perceived } \\
\text { child to be skinny even when child had healthy } \\
\text { weight. Grandmothers promoted consumption of } \\
\text { large amounts of food to grow healthy and strong }\end{array}$} \\
\hline U.S. & $\mathrm{n}=31$ & & \\
\hline Valencia et al. (82) & Focus groups & \multirow[t]{2}{*}{ Latino } & \multirow{2}{*}{$\begin{array}{l}\text { Mothers had difficulty in negotiating about } \\
\text { healthy feeding practices with grandparents. } \\
\text { Grandparents often thought that the grandchild } \\
\text { was underfed, and had to be fed more to promote } \\
\text { weight gain in infancy }\end{array}$} \\
\hline U.S. & $\mathrm{n}=53$ & & \\
\hline Jain et al. (83) & Focus groups & Black $(n=13)$ & \multirow{2}{*}{$\begin{array}{l}\text { Mothers believed that having a large body size } \\
\text { was culturally acceptable if child was healthy and } \\
\text { active. Mothers reported difficulties in negotiating } \\
\text { with grandparents on how much to feed child }\end{array}$} \\
\hline U.S. & $\mathrm{n}=18$ & White $(n=5)$ & \\
\hline Kimbro et al. (84) & Cross-sectional & \multirow[t]{2}{*}{ Hispanic, White } & \multirow{2}{*}{$\begin{array}{l}\text { Mexican immigrant mothers were more likely } \\
\text { to breastfeed longer ( }>6 \text { months) as compared } \\
\text { to whites (5.24 months) or Mexican-Americans } \\
\text { (3.68 months) }\end{array}$} \\
\hline U.S. & $\mathrm{n}=3,626$ & & \\
\hline Power et al. (85) & Longitudinal observation & \multirow[t]{2}{*}{ Hispanic } & \multirow{2}{*}{$\begin{array}{l}\text { Immigrant mothers used pressure tactics to make } \\
\text { children consume more food, used food as a } \\
\text { reward and limited unhealthy food than U.S. born } \\
\text { mothers }\end{array}$} \\
\hline U.S. & $\mathrm{n}=169$ & & \\
\hline Evans et al. (86) & Cross-sectional & \multirow[t]{2}{*}{ Hispanics, Black } & \multirow{2}{*}{$\begin{array}{l}\text { Using food to calm the child was higher in } \\
\text { Spanish-speaking Hispanic and Black parents } \\
\text { than English-speaking Hispanics }\end{array}$} \\
\hline U.S & $\mathrm{n}=721$ & & \\
\hline Lee et al. (87) & Semi-structured & \multirow[t]{3}{*}{ Chinese } & \multirow{3}{*}{$\begin{array}{l}\text { Less acculturated Chinese-speaking } \\
\text { grandmothers supported infant formulas because } \\
\text { of non-availability of information on benefits of } \\
\text { breastfeeding in Chinese }\end{array}$} \\
\hline & interviews & & \\
\hline China & $\mathrm{n}=22$ & & \\
\hline
\end{tabular}




\section{Conclusion}

The birth of a new baby gives grandparents a new chance to reenter and reconnect with their adult children who typically seek parental assistance. Thus, the first two years are a unique opportunity for grandparents to promote healthy eating for children. At present, few studies that include the actual grandparent have investigated whether grandparent involvement is related to feeding practices and subsequent weight outcomes in children aged 0-2 years. Most of these studies are either focus group studies that include parents or self-reported data from parents, without the actual inclusion of grandparents. None of these studies clearly define what a healthy diet is and how is it measured in young children. In addition, there are many confounding variables that have not been accounted for such as maternal or paternal grandparents, actual time spent by grandparents with the grandchildren and the degree of involvement of grandparents in co resident households. Majority of studies included are qualitative reviews as there exists many challenges in studying this topic. These include difficulties of randomized intervention designs in infant feeding and longitudinal studies as children may move out of grandparents' house or grandparents may not live long enough to provide any conclusive results.

Interventions for childhood obesity are increasingly incorporating a family-focused approach. Whereas, co-parenting between parents is well documented, the nature of co-parenting between parents and grandparents, (competitive or cooperative) and its influence on feeding practices and weight gain in the child remains a missing link. Identification of successful characteristics of grandparent/parents who co-parent in triadic feeding interactions might promote healthy feeding practices and reduce the risk of obesity in the child.

Other areas that warrant further investigation are the effect of grandparents' healthy eating, appropriate nutrition knowledge, attitudes and beliefs about nutrition; and Body Mass Index [BMI] on child feeding practices and obesity risk at multiple time points between 3-24 months.

Finally, it is critical to investigate the relative contribution of the above factors within the context of race/ethnicity, degree of acculturation and cultural norms of the grandparents and parents. These critical barriers to obesity prevention need to be addressed in order provide child and health care professionals the tools to create robust, effective interventions that incorporate grandparents as important partners in obesity prevention.

\section{Conflict of Interest}

Jeanne Freeland-Graves: The author declares that there is no conflict of interest regarding the publication of this article.

Deborah Jacobvitz: The author declares that there is no conflict of interest regarding the publication of this article.

Prageet Sachdev: The author declares that there is no conflict of interest regarding the publication of this article.

\section{Source of Funding: The Bess Heflin Centennial Professorship Acknowledgements}

Bess Heflin Centennial Professorship \# 3086006875

\section{References}

1. Hales CM, Carroll MD, Fryar CD, Ogden CL. Prevalence of Obesity Among Adults and Youth: United States, 2015-2016. NCHS Data Brief. 2017;(288):1-8.

2. Ogden CL, Carroll MD, Kit BK, Flegal KM. Prevalence of childhood and adult obesity in the United States, 2011-2012. JAMA. 2014;311(8):806-814. doi: 10.1001/jama.2014.732

3. Ogden CL, Carroll MD, Fryar CD, Flegal KM. Prevalence of obesity among adults and youth: United States, 2011-2014. NCHS Data Brief. 2015;(219):1-8.

4. Rolls BJ. The supersizing of America: portion size and the obesity epidemic. Nutr Today. 2003;38(2):42-53.

5. Polley DC, Spicer MT, Knight AP, Hartley BL. Intra-familial correlates of overweight and obesity in African-American and NativeAmerican grandparents, parents, and children in rural Oklahoma. J Am Diet Assoc. 2005;105(2):262-265.

6. Jabs J, Devine CM. Time scarcity and food choices: an overview. Appetite. 2006;47(2):196-204.

7. Mulligan GM, Brimhall D, West J. Child Care and Early Education Arrangements of Infants, Toddlers, and Preschoolers: 2001. Statistical Analysis Report. NCES 2006-039. 2005;2006-2039.

8. Haire-Joshu D, Tabak R. Preventing Obesity Across Generations: Evidence for Early Life Intervention. Annu Rev Public Health. 2016;37:253-271.doi:10.1146/annurev-publhealth-032315-021859

9. Pearce A, Li L, Abbas J, Ferguson B, Graham H, Law C. Is childcare associated with the risk of overweight and obesity in the early years? Findings from the UK Millennium Cohort Study. Int J Obes (Lond). 2010;34(7):1160-1168. doi: 10.1038/ijo.2010.15

10. Bureau USC. 10 percent of grandparents live with a grandchild: Census bureau reports 2014. Retrieved from //www.census.gov/ newsroom/press-releases/2014/cb14-194.html. Accessed Dec 6, 2017.

11. Laughlin, L. Who's Minding the Kids? Child Care Arrangements: Spring 2011. Current Population Reports, Washington. DC:US Census Bureau 2013;70-135.

12. Pulgarón ER, Patiño-Fernández AM, Sanchez J, Carrillo A, Delamater AM. Hispanic children and the obesity epidemic: exploring the role of abuelas. Fam Syst Health. 2013;31(3):274-279. doi: 10.1037/ a0034208

13. Davis MM, McGonagle K, Schoeni RF, Stafford F. Grandparental and parental obesity influences on childhood overweight: implications for primary care practice. J Am Board Fam Med. 2008;21(6):549554. doi: 10.3122/jabfm.2008.06.070140

14.Jiang L. The Impacts of Grandparental Caregiving on Early Childhood Obesity in China Doctoral dissertation, University of California: Los Angles 2015. 
15. Watanabe E, Lee JS, Kawakubo K. Associations of maternal employment and three-generation families with pre-school children's overweight and obesity in Japan. Int J Obes (Lond). 2011;35(7):945-952. doi: 10.1038/ijo.2011.82

16. Li B, Adab P, Cheng KK. The role of grandparents in childhood obesity in China-evidence from a mixed methods study. Int J Behav Nutr Phys Act. 2015;(12):91-99.

17. Formisano A, Hunsberger M, Bammann K, Vanaelst B, Molnar D, Moreno LA, et al. Family structure and childhood obesity: results of the IDEFICS Project. Public Health Nutr. 2014;17(10):2307-2315. doi: $10.1017 /$ S1368980013002474

18. Tanskanen AO. The association between grand maternal investment and early years overweight in the UK. Evol Psychol. 2013;11(2):417425.

19. Cunningham SA, Elo IT, Herbst K, Hosegood V. Prenatal development in rural South Africa: Relationship between birth weight and access to fathers and grandparents. Popul Stud (Camb). 2010;64(3):229246. doi: 10.1080/00324728.2010.510201

20. Pulgaron ER, Marchante AN, Agosto Y, Lebron CN, Delamater AM. Grandparent involvement and children's health outcomes: The current state of the literature. Fam Syst Health. 2016;34(3):260269. doi: $10.1037 /$ fsh 0000212

21. Emmott EH, Mace R. Practical support from fathers and grandmothers is associated with lower levels of breastfeeding in the UK Millennium Cohort Study. PLoS One. 2015;10(7):e0133547. doi: 10.1371/journal.pone. 0133547

22. Kaneko A, Kaneita Y, Yokoyama E, Miyake T, Harano S, Suzuki K, et al. Factors associated with exclusive breast-feeding in Japan: for activities to support child-rearing with breast-feeding. J Epidemiol. 2006;16(2):57-63.

23. Liu P, Qiao L, Xu F, Zhang M, Wang Y, Binns CW. Factors associated with breastfeeding duration a 30-month cohort study in northwest China. J Hum Lact. 2013;29(2):253-259. doi: 10.1177/0890334413477240

24. Susin LR, Giugliani ER, Kummer SC. Influence of grandmothers on breastfeeding practices. Rev Saude Publica. 2005;39(2):141-147.

25. Mahoney MC, James DM. Predictors of anticipated breastfeeding in an urban, low-income setting. J Fam Pract. 2000;49(6):529-533.

26. Pilkauskas NV. Breastfeeding initiation and duration in coresident grandparent, mother and infant households. Matern Child Health J. 2014;18(8):1955-1963. doi: 10.1007/s10995-014-1441-z

27. Baughcum AE, Burklow KA, Deeks CM, Powers SW, Whitaker RC. Maternal feeding practices and childhood obesity: a focus group study of low-income mothers. Arch Pediatr Adolesc Med. 1998;152(10):1010-1014.

28. Ingram J, Johnson D, Hamid N. South Asian grandmothers' influence on breast feeding in Bristol. Midwifery. 2003;19(4):318-327.

29. Bentley ME, Dee DL, Jensen JL. Breastfeeding among low income, African-American women: power, beliefs and decision making. J Nutr. 2003;133(1):305S-309S. practices in Malawi: timing, reasons, decision makers, and child health consequences. Food Nutr Bull. 2007;28(1):90-99.

31. Walsh A, Kearney L, Dennis N. Factors influencing first-time mothers' introduction of complementary foods: a qualitative exploration. BMC Public Health 2015;15:939. doi: 10.1186/s12889$015-2250-z$

32. Carling SJ, Demment MM, Kjolhede CL, Olson CM. Breastfeeding duration and weight gain trajectory in infancy. Pediatrics. 2015;135(1):111-119. doi: 10.1542/peds.2014-1392

33. Morgan JB, Lucas A, Fewtrell MS. Does weaning influence growth and health up to 18 months? Arch Dis Child. 2004;89(8):728-733. doi: $10.1136 /$ adc.2003.036137

34. Griffiths LJ, Smeeth L, Hawkins SS, Cole TJ, Dezateux C. Effects of infant feeding practice on weight gain from birth to 3 years. Arch Dis Child. 2009;94(8):577-582. doi: 10.1136/adc.2008.137554

35. Sloan S, Gildea A, Stewart M, Sneddon H, Iwaniec D. Early weaning is related to weight and rate of weight gain in infancy. Child Care Health Dev. 2008;34(1):59-64. doi: 10.1111/j.1365-2214.2007.00771.x

36. Baker JL, Michaelsen KF, Rasmussen KM, Sorensen TI. Maternal prepregnant body mass index, duration of breastfeeding, and timing of complementary food introduction are associated with infant weight gain. Am J Clin Nutr. 2004;80(6):1579-1588.

37. Koletzko B, von Kries R, Closa R, Escribano J, Scaglioni S, Giovannini $\mathrm{M}$, et al. Can infant feeding choices modulate later obesity risk? Am J Clin Nutr. 2009;89(5):1502S-1508S. doi: 10.3945/ajcn.2009.27113D

38. Yan J, Liu L, Zhu Y, Huang G, Wang PP. The association between breastfeeding and childhood obesity: a meta-analysis. BMC Public Health. 2014;14:1267. doi: 10.1186/1471-2458-14-1267

39. Harder T, Bergmann R, Kallischnigg G, Plagemann A. Duration of breastfeeding and risk of overweight: a meta-analysis. Am J Epidemiol. 2005;162(5):397-403.

40. Vail B, Prentice P, Dunger DB, Hughes IA, Acerini CL, Ong KK. Age at weaning and infant growth: primary analysis and systematic review. J Pediatr. 2015; 167(2): 317-324.e1. doi: 10.1016/j. jpeds.2015.05.003

41. Murphy SE, Jacobvitz DB, Hazen NL. What's so bad about competitive coparenting? Family-level predictors of children's externalizing symptoms. J Child Fam Stud. 2016;25(5):1684-1690.

42. Umemura T, Christopher C, Mann T, Jacobvitz D, Hazen N. Coparenting problems with toddlers predict children's symptoms of psychological problems at age 7. Child Psychiatry Hum Dev. 2015;46(6):981-996. doi: 10.1007/s10578-015-0536-0

43. Eli K, Howell K, Fisher PA, Nowicka P. A question of balance: Explaining differences between parental and grandparental perspectives on preschoolers' feeding and physical activity. Soc Sci Med. 2016;154:28-35. doi: 10.1016/j.socscimed.2016.02.030

44. Kretchmar MD, Jacobvitz DB. Observing mother-child relationships across generations: Boundary patterns, attachment, and the transmission of caregiving. Fam Process. 2002 Fall;41(3):351-374.

30. Kerr RB, Berti PR, Chirwa M. Breastfeeding and mixed feeding 
45. Jacobvitz DB, Morgan E, Kretch mar MD, Morgan Y. The transmission of mother-child boundary disturbances across three generations. Dev Psychopathol. 1991;3(4):513-527.

46. Jacobvitz D, Hazen N, Zaccagnino M, Messina S, Beverung L. Frightening maternal behavior, infant disorganization, and risks for psychopathology. The Origins and Organization of Adaptation and Maladaptation 2011;36:283-322.

47. Jacobvitz D, Leon K, Hazen N. Does expectant mothers' unresolved trauma predict frightened/frightening maternal behavior? Risk and protective factors. Dev Psychopathol. 2006 Spring;18(2):363-379.

48. Saunders R, Jacobvitz D, Zaccagnino M, Beverung LM, Hazen N. Pathways to earned-security: The role of alternative support figures. Attach Hum Dev. 2011;13(4):403-420. doi: 10.1080/14616734.2011.584405

49. Leon K, Jacobvitz DB. Relationships between adult attachment representations and family ritual quality: A prospective, longitudinal study. Fam Process. 2003 Fall;42(3):419-432.

50. Umemura T, Jacobvitz D, Messina S, Hazen N. Do toddlers prefer the primary caregiver or the parent with whom they feel more secure? The role of toddler emotion. Infant Behav Dev. 2013;36(1):102-114. doi: $10.1016 /$ j.infbeh.2012.10.003

51. Jacobvitz D, Reisz S, Messina S, Pettit K, Poulsen H, Hazen N. Family dynamics from an attachment perspective, Parents'joint attachment pairings predict couple and parent-infant feeding interactions. Society for Research in Child Development: Philadelphia, PA.

52. Anderson SE, Sacker A, Whitaker RC, Kelly Y. Self-regulation and household routines at age three and obesity at age eleven: longitudinal analysis of the UK Millennium Cohort Study. Int J Obes (Lond). 2017;41(10):1459-1466. doi: 10.1038/ijo.2017.94

53. Ruiz DS, Zhu CW, Crowther MR. Noton their own again: Psychological, social, and health characteristics of custodial African American grandmothers. J Women Aging 2003;15:167-184.

54. Gibson EL, Wardle J, Watts CJ. Fruit and vegetable consumption, nutritional knowledge and beliefs in mothers and children. Appetite. 1998;31(2):205-228.

55. Higgins MM, Murray BJ. Nutrition-related practices and attitudes of Kansas skipped-generation (s) caregivers and their grandchildren. Nutrients. 2010;2(12):1188-1211. doi: 10.3390/nu2121188

56. Variyam JN, Blaylock J, Lin BH, Ralston K, Smallwood D. Mother's nutrition knowledge and children's dietary intakes. Am J Agric Econ. 1999;81(2):373-384.

57. Burchi F. Child nutrition in Mozambique in 2003: The role of mother's schooling and nutrition knowledge. Econ Hum Biol. 2010;8(3):331345. doi: $10.1016 /$ j.ehb.2010.05.010

58. Aubel J, Tour'e I., Diagne M. Senegalese grandmothers promote improved maternal and child nutrition practices: the guardians of tradition are not averse to change. Soc Sci Med. 2004;59(5):945-959.

59. Tan C, Luo J, Zong R, Fu C, Zhang L, Mou J, et al. Nutrition knowledge, attitudes, behaviours and the influencing factors among nonparent caregivers of rural left-behind children under 7 years old in China. Public Health Nutr. 2010;13(10):1663-8. doi: 10.1017/ S1368980010000078
60. Kicklighter JR, Whitley DM, Kelley SJ, Shipskie SM, Taube JL, Berry RC. Grandparents raising grandchildren: A response to a nutrition and physical activity intervention. J Am Diet Assoc. 2007;107(7):1210-1213.

61. Ganthavorn C, Hughes JS. Promoting healthy lifestyles among grandparents raising grandchildren in Riverside County. Journal of extension 2007;45 (1).

62. Leone WVS, Rollins E. School of Public Health (2017), Executive summary. A grandmother-inclusive approach to improve maternal nutrition \& infant and young child feeding in Sierra Leone: The Mamanieva Project 2017.

63. Duquin M, McCrea J, Fetterman D, Nash S. A faith-based intergenerational health and wellness program. J Intergener Relatsh. 2004;2:105-118.

64. Eli K, Hornell A, Malek ME, Nowicka P. Water, juice, or soda? Mothers and grandmothers of preschoolers discuss the acceptability and accessibility of beverages. Appetite. 2017;112:133-142. doi: 10.1016/j.appet.2017.01.011

65. Jingxiong J, Rosenqvist U, Huishan W, Greiner T, Guangli L, Sarkadi A. Influence of grandparents on eating behaviors of young children in Chinese three-generation families. Appetite. 2007;48(3):377383.

66. Peters J, Parletta N, Campbell K, Lynch J. Parental influences on the diets of 2- to 5-year-old children: Systematic review of qualitative research. J Early Child Res. 2014;12:3-19.

67. McGarvey EL, Collie KR, Fraser G, Shufflebarger C, Lloyd B, Norman Oliver M. Using focus group results to inform preschool childhood obesity prevention programming. 『Ethn Health. 2006;11(3):265285.

68. Crawford P, Townsend M, Metz D et al. How can Californians be overweight and hungry? Calif Agric 2004;58(1):12-17.

69. Sherry B, McDivitt J, Birch LL et al. Attitudes, practices, and concerns about child feeding and child weight status among socioeconomically diverse white, Hispanic, and African-American mothers. J Am Diet Assoc. 2004;104(2):215-221.

70. Klohe-Lehman DM, Freeland-Graves J, Anderson ER, McDowell T, Clarke KK, Hanss-Nuss $\mathrm{H}$, et al. Nutrition knowledge is associated with greater weight loss in obese and overweight low-income mothers. J Am Diet Assoc. 2006;106(1):65-75.

71. Spence AC, McNaughton SA, Lioret S, Hesketh KD, Crawford DA, Campbell KJ. A health promotion intervention can affect diet quality in early childhood J Nutr. 2013;143(10):1672-1678. doi: 10.3945/ jn.113.177931

72. Polley DC, Spicer MT, Knight AP, Hartley BL. Intrafamilial correlates of overweight and obesity in African-American and NativeAmerican grandparents, parents, and children in rural Oklahoma. J Am Diet Assoc. 2005;105(2):262-265.

73. Davis MM, McGonagle K, Schoeni RF, Stafford F. Grandparental and parental obesity influences on childhood overweight: implications for primary care practice. J Am Board Fam Med. 2008;21(6):549554. doi: 10.3122/jabfm.2008.06.070140 
74. Faith MS, Hittner JB. Infant temperament and eating style predict change in standardized weight status and obesity risk at 6 years of age. Int J Obes (Lond). 2010;34(10):1515-1523. doi: 10.1038/ ijo. 2010.156

75. Slining MM, Adair L, Goldman BD, Borja J, Bentley M. Infant temperament contributes to early infant growth: A prospective cohort of African American infants. Int J Behav Nutr Phys Act. 2009;6:51. doi: 10.1186/1479-5868-6-51

76. Wasser H, Bentley M, Borja J, Davis Goldman B, Thompson A, Slining $\mathrm{M}$, et al. Infants perceived as "fussy" are more likely to receive complementary foods before 4 months. Pediatrics. 2011;127(2):229237. doi: $10.1542 /$ peds.2010-0166

77. Bergmeier H, Skouteris H, Horwood S, Hooley M, Richardson B. Associations between child temperament, maternal feeding practices and child body mass index during the preschool years: A systematic review of the literature. Obes Rev. 2014;15(1):9-18. doi: 10.1111/obr.12066

78. Burdette HL, Whitaker RC, Hall WC, Daniels SR. Maternal infantfeeding style and children's adiposity at 5 years of age. Arch Pediatr Adolesc Med 2006;160:513-520.

79. Contento IR, Basch C, Zybert P. Body image, weight, and food choices of Latina women and their young children. J Nutr Educ Behav. $2003 ; 35(5): 236-248$

80. Crawford PB, Gosliner W, Anderson C, Strode P, Becerra-Jones Y, Samuels S, et al. Counseling Latina mothers of preschool children about weight issues: suggestions for a new framework. J Am Diet Assoc. 2004;104(3):387-394.

81. Lindsay AC, Sussner KM, Greaney ML, Peterson KE. Latina mothers' beliefs and practices related to weight status, feeding, and the development of child overweight. Public Health Nurs. 2011;28(2):107-118. doi: 10.1111/j.1525-1446.2010.00906.x

82. Valencia AC, Thomson CA, Duncan B, Arthur A. Evaluating Latino WIC Mothers' Perceptions of Infant's Healthy Growth: A Formative Assessment. Matern Child Health J. 2016;20(3):525-533. doi: 10.1007/s10995-015-1850-7
83. Jain A, Sherman SN, Chamberlin LA, Carter Y, Powers SW, Whitaker RC. Why don't low-income mothers worry about their preschoolers being overweight?. Pediatrics. 2001;107(5):1138-1146.

84. Kimbro RT, Lynch SM, McLanahan S. The influence of acculturation on breastfeeding initiation and duration for Mexican-Americans. Popul Res Policy Rev. 2008;27:183-199. doi: 10.1007/s11113-0079059-0

85. Power TG, O’Connor TM, Orlet Fisher J, Hughes SO. Obesity risk in children: the role of acculturation in the feeding practices and styles of low-income Hispanic families. Child Obes. 2015;11(6):715721. doi: $10.1089 /$ chi.2015.0036

86. Evans A, Seth JG, Smith S, Harris KK, Loyo J, Spaulding C, et al. Parental feeding practices and concerns related to child underweight, picky eating, and using food to calm differ according to ethnicity/race, acculturation, and income. Matern Child Health J. 2011;15(7):899909. doi: 10.1007/s10995-009-0526-6

87. Lee A. Understanding Infant Feeding Practices among Chinese Mothers in New York City. 2013;Public Health, Food Studies and Nutrition-Theses. Paper 2.

88. McConahy KL, Smiciklas-Wright H, Birch LL, Mitchell DC, Picciano MF. Food portions are positively related to energy intake and body weight in early childhood. J Pediatr. 2002;140(3):340-347.

89. Ahluwalia IB, D’Angelo D, Morrow B, McDonald JA. Association between acculturation and breastfeeding among hispanic women data from the pregnancy risk assessment and monitoring system. J Hum Lact. 2012;28(2):167-173. doi: 10.1177/0890334412438403

90. Kaiser LL, Melgar-Qui \nonez HR, Lamp CL, Johns MC, Harwood JO. Acculturation of Mexican-American mothers influences child feeding strategies. J Am Diet Assoc. 2001;101(5):542-547.

91. Seth JG, Evans AE, Harris KK, Loyo JJ, Ray TC, Spaulding C, et al. Preschooler Feeding Practices and Beliefs: Differences Among Spanish-and English-speaking WIC Clients. Fam Community Health. $2007 ; 30(3): 257-270$. 